\title{
Effects of switching from olanzapine to aripiprazole on the metabolic profiles of patients with schizophrenia and metabolic syndrome: a double-blind, randomized, open-label study [Corrigendum]
}

Wani RA, Dar MA, Chandel RK, et al. Neuropsychiatric Disease and Treatment. 2015;11:685-693.

Title of paper should have been "Effects of switching from olanzapine to aripiprazole on the metabolic profiles of patients with schizophrenia and metabolic syndrome: a randomized, open-label study".

\section{Publish your work in this journal}

Neuropsychiatric Disease and Treatment is an international, peerreviewed journal of clinical therapeutics and pharmacology focusing on concise rapid reporting of clinical or pre-clinical studies on a range of neuropsychiatric and neurological disorders. This journal is indexed on PubMed Central, the 'PsycINFO' database and CAS, and is the official journal of The International Neuropsychiatric Association (INA). The manuscript management system is completely online and includes a very quick and fair peer-review system, which is all easy to use. Visit http://www.dovepress.com/testimonials.php to read real quotes from published authors. submit your manuscript | www.dovepress.com

Dovepress

http://dx.doi.org// 0.2/47/NDT.S85295 